\title{
The perspectives of the doctoral students of the University of Debrecen related to migration
}

\author{
Fruzsina Szigeti ${ }^{1}$, \\ Recommended citation: \\ Szigeti, F. (2020). The perspectives of the doctoral students of the University of Debrecen related to migration. \\ Central European Journal of Educational Research, 2(1), 103 - 111.
}

\begin{abstract}
Research on migration processes in recent years has highlighted the fact that migration is becoming more common among younger and more educated people. We believe that it is worth meeting the (self)selection of (potential) migrants at the beginning of the process, and also, measuring the willingness to migrate is important. During our research, we investigated the migration plans of $\mathrm{PhD}$ students at the University of Debrecen through paper-based questionnaires. In our study, we seek to determine the extent to which $\mathrm{PhD}$ students in Debrecen are willing to migrate. Also, we investigate what the fundamental difference is between $\mathrm{PhD}$ students with the intent of migration and those without. 53.4\% of the responding doctoral students intend to stay in Hungary after completing their doctoral training, while $46.6 \%$ consider it possible to settle abroad. It has been observed that strong and weak bonds of those who wish to stay in the country of residence are significant, while those who wish to stay abroad own migration shells.
\end{abstract}

Keywords: embeddedness; higher education; $\mathrm{PhD}$ education; intention to migrate

\section{Introduction}

In this study, we examine propensity to migration of doctoral students based on data obtained from the PhD Student's Quality of Life and Migration Potential (PSQLMA) database. The database contains the questionnaire responses of the doctoral students with active student status in the spring semester of 2016/2017 and the autumn semester of 2017/2018 at the University of Debrecen. The study proves to fill research gaps since there is little data available on $\mathrm{PhD}$ students in international higher education research (Papp Z. \& Csata, 2014), and their intention to migrate is usually not reported.

Research on migration processes in recent years has shown that Hungarians wishing to emigrate are younger and highly qualified (Blaskó \& Gödri, 2014; Blaskó \& Ligeti \& Sik, 2014; Dabasi Halász \& Kiss, 2018; Siskáné Szilasi \& Halász, 2018). To explore the background and motivations of actual migration as an action, it is necessary to meet the (self)selection of (potential) migrants early in the process, and it is essential to assess the willingness to migrate (Ajzen, 1991, 2005; Gödri \& Feleky, 2013).

In our work, we aim at examining the migration potential of the doctoral students of the University of Debrecen and presenting the influencing factors thereof. In our study, we seek to determine the extent to which $\mathrm{PhD}$ students in Debrecen are willing to migrate, and what the difference is between $\mathrm{PhD}$ students with the intent of migration and those without. In order to answer these questions, it is important to know the demographic characteristics of doctoral students (sex, age, marital status), socioeconomic status (parents' education, type of settlement, financial situation), the network embeddedness against migration (belonging to a local community, family/friends and networks), their relationships supporting migration called as migration shell by Sik (2018), and their mobility capital (foreign language usage, previous experience abroad, relationship abroad).

${ }^{1}$ University of Debrecen, Debrecen, Hungary; szigeti.fruzsina.89@gmail.com 


\section{Literature background}

Migration is a multi-stage process. Depending on the preferences and goals, the process begins with considering migration, followed by the intention to migrate and ends with the concrete action depending on the discretion of the supporting and inhibiting factors. A decision-making phase can be detected in the migration process, within which the intention to migrate and the implementation phase can be separated (Gödri \& Feleky, 2013; Kley \& Mulder, 2010).

Also, selection can be seen between planning and executing the migration (Gödri \& Feleky, 2013). According to the theory of planned behaviour, the intention to migrate is transformed into concrete action and real migration by the consideration of the expected advantages and disadvantages of migration, the perception of subjective norms (external expectations, social pressures) related to migration, and perceived action control (Ajzen, 1991, 2005).

Our research focuses solely on the propensity to migrate. This measures the willingness to work and/or to study abroad, the proportion of people within the population who are willing to leave their homeland who consider emigration possible (Sik \& Seitl, 2016).

Theories explaining migration potential and actual migration, such as push and pull theory, micro and macro theory of neoclassical economics, new economics theory, dual labour market theory, world-systems theory, network theory, institutional theory and cumulative causation theory, clearly indicate the complexity of the (potential) migration processes and the underlying causes. These may include better quality of living, a higher level of income, career advancement, effort to maximise income, avoidance of unemployment, or access to better public institutions and services (Douglas et al., 1993; Hautzinger \& Hegedüs \& Klenner, 2014; Huzdik, 2014; Sik, 2012).

Migration and intention to migrate are crucial for both the sending and host countries, as it can cause several demographic, economic and social changes. In the host countries, the effects of the immigrating labours on wages, economic growth and unemployment are first and foremost known. In contrast, in the issuing countries, the phenomenon of 'brain drain' is highlighted so the loss of working-age population with the highest levels of education and training (Blaskó \& Gödri, 2014; Pálinkó, 2013).

The fundamentally negative connotation of the term "brain drain" suggests that when the most highly educated ones move from their home country where they have acquired their human capital, they are more likely to increase the economic and intellectual capital of the host country rather than their sending country (Csanády et al., 2008). Young talents migrate to the place where the most distinguished researchers work, and where they find a secure position in the labour market and a secure existential position. In their case, the likelihood of giving up an already well-established career and never returning to their homeland is high (Csanády et al., 2008; Csermely \& Málnási-Csizmadia \& Kovács, 2002).

Beyond the damaging effects of the brain drain, positive views can also be seen. The opportunity for a successful and recognized foreign career to (further) study encourages those staying at home, which, through the indirect effect of brain drain, may result in a higher proportion of highly qualified people in the sending country, i.e. brain gain (Huzdik, 2014; Stark \& Helmenstein \& Prskawetz, 1997). Positive attitudes also emphasize that remittances from the host country can also increase the income of the sending country. Moreover, brain drain actually prevents brain waste and thus the loss of unused capacities and competences (Berényi, 1993; Golovics, 2015). In the globalized world, the type of researcher connected to several scientific centres and countries have appeared. Besides the homeland and their first host country, they are linked to other localities and act as a kind of scientific broker through their extensive network of relationships (Pusztai et al., 2016).

Given the positive and negative effects of brain drain, we focus our work on the intent of migration among PhD students at the University of Debrecen.

Of course, we are aware that not all desires to migrate will be realised in the future, which may be due to a lack of essential resources (financial capital, language knowledge, networking), unforeseeable costs, lack of demand in the targeted country/countries, the occurrence of unexpected events or the lack of well-grounded and reasoned intention to migration (Gödri \& Feleky, 2013). At 
any rate, we believe that the ideas will also help to identify the predictors of migration among $\mathrm{PhD}$ students in Debrecen.

\section{Research design and Methods}

In this paper, we outline the intention of $\mathrm{PhD}$ students of the University of Debrecen to migrate. We hypothesize that young and single doctoral students are more likely to settle abroad than those who are older and those who have a family (Blaskó \& Gödri, 2014; Fassmann \& Musil, 2013; Kley, 2011; Ruff, 2012; Sik, 2018; Sik \& Simonovits, 2002; Siskáné Szilasi \& Halász, 2018).

We hypothesize that students having a better grasp of a foreign language and believing that they can easily and flexibly adapt to the culture of the country, as they can speak the official language of the country, plan emigration in a higher ratio (Deákné Dusa, 2017; Sik, 2018; Sik \& Örkény, 2003).

We also hypothesize a significant relationship between social relationships and the intention to migrate. We believe that previous study and/or employment abroad and the network of contacts abroad reinforce the intention to migrate, while social embeddedness counteracts the intention to migrate (Bernát, 2006; Deákné Dusa, 2017; Haug, 2008; Németh \& Lőrincz, 2019; Portes, 2008; Portes \& Sensenbrenner, 1998; Sik, 2018; Simonovits, 2003; Székely \& Pitó, 2010).

In our analysis, we use the PSQLMA 2017 database, which includes PhD students studying at the University of Debrecen with active student status in the spring semester of 2016/2017 and autumn semester of 2017/2018 ( $\mathrm{N}=191$ ). The questionnaires were anonymous, voluntary and selfadministered. The PhD students filled them by themselves without intervention of me. Since the complete current list of populations is not available, we sought to achieve similarity between the sample and the general population through quota sampling. The sample is representative of the faculties and training fields of the University of Debrecen, accounting for nearly $25 \%$ of the population of 2017.

\section{Results}

$53.4 \%$ of the responding doctoral students intend to stay in Hungary after completing their doctoral studies, while $46.6 \%$ consider it possible to settle abroad ${ }^{2}$. To be able to distinguish between those who want to go abroad and those who have a strong domestic connection, it is important to investigate the background variables.

There is no significant difference between those who intend to stay and those who want to move abroad concerning sex $(\mathrm{p}=0.132)$, marital status $(\mathrm{p}=0.079)$, age $(\mathrm{p}=0.456)$, level of language proficiency $(\mathrm{p}=0.750)$, previous study abroad $(\mathrm{p}=0.081)$, previous employment abroad $(\mathrm{p}=0.713)$, type of settlement $(\mathrm{p}=0.100)$, educational level of the mother $(\mathrm{p}=0.422)$ and educational level of the father $(\mathrm{p}=0.371)$. In research focusing on higher educational students, these variables generally produced significant differences (Blaskó \& Gödri, 2014; Deákné Dusa, 2017; Fassmann \& Musil, 2013; Kley, 2011; Ruff, 2012; Sik, 2018; Sik \& Simonovits, 2002; Siskáné Szilasi \& Halász, 2018). A tendency could be detected among the examined doctoral students that a greater proportion of men, singles, younger students and those coming from larger settlements can settle abroad for shorter or longer periods. The greater willingness of men to migrate may be explained by the fact that their social self-image is much better suited for adventure and risk-taking compared to women, and are also more motivated by the possibility for extra income abroad (Sik, 2018). However, in this circle, sex is the nondifferentiated. Cohabiting and married couples will have to face the higher costs of ending domestic status when migrating with a complete family, compared to single people. At the same time, typically, at least two adults have to be established in the labour market in this case. This may result in higher intentions to migrate among single people (Blaskó \& Gödri, 2014; Kley, 2011; Ruff, 2012).

The higher willingness of young people can be associated with the desire for adventure and breaking out. Also, the earlier the stage the person is in, in his/her career, the longer he/she has to stay abroad, the more likely he/she will recover the costs of external migration (Blaskó \& Gödri, 2014; Fassmann \& Musil, 2013; Murphy-Lejeune, 2002; Ruff, 2012; Sik, 2018; Sik \& Simonovits, 2002). The

\footnotetext{
2 Ratio contains long- and short-term plans of abroad.
} 
higher willingness to migrate among people coming from larger cities can result from the fact that large cities are more involved in the global labour market, communication and cultural relations than those coming from small settlements (Sik, 2018).

The resources of mobility capital are also used to measure the willingness to migrate (Deákné Dusa, 2017; Murphy-Lejeune, 2002; Sik, 2018; Sik \& Örkény, 2003). The results of the Chi-square test show that, according to the level of self-rated language usage $(\mathrm{p}=0.750)$ and previous experience abroad ( $\mathrm{p}=0.081$ ), there is no significant difference between those who intend to go abroad and those who rejecting it due to strong domestic ties, presumably because the examined doctoral students form a homogeneous group in terms of language usage and mobility experience.

$68.1 \%$ of $\mathrm{PhD}$ respondents speak at least one foreign language, mostly English. Only $14 \%$ of the respondents had studied abroad for at least four months, and only $7.8 \%$ had paid work abroad ${ }^{3}$. Regarding the background of these low rates, it should be noted that due to the incomplete or weak network of higher education of the Transtisza region, students learning at the University of Debrecen come mainly from this region (Hegedüs, 2015; Teperics, 2003), having lower social status. The investigated students were characterized with intergenerational mobility and were not predominantly raised in a family where family socialization would have provided favourable conditions either for the scientific career or for gaining experience abroad. 51.2\% of mothers have at least secondary educational certificate, and $37.4 \%$ of fathers are non-graduates. Following Sik (2018), we examined the relationships of $\mathrm{PhD}$ students abroad with the questions 'Do you have a friend who can help you find a job abroad?' and 'Do you have an acquaintance who can help you find a place of residence abroad?' In both cases, the Chi-square test showed a significant difference between those who want to stay and those who want to go abroad ( $p_{\text {job seeking }}=0.008$; $p_{\text {place of living }}=0.025$ ) (Figure 1 ). Those who wish to stay abroad have a larger network of contacts than those who wish to stay, which can be explained by the network theory. The existence of networks reduces the risk and costs of migration. The reduction can be detected since if there is a connection in the destination country, it can facilitate job seeking, access to job and reduces the uncertainty of finding a job. The costs are the highest for the first migrants, while the family, friends and relatives who follow them face significantly lower costs. All in all, each new (im)migration reduces the migration cost for the next wave and increases its connection (Douglas et al., 1993; Sik, 2012; Tilly \& Brown, 1967).

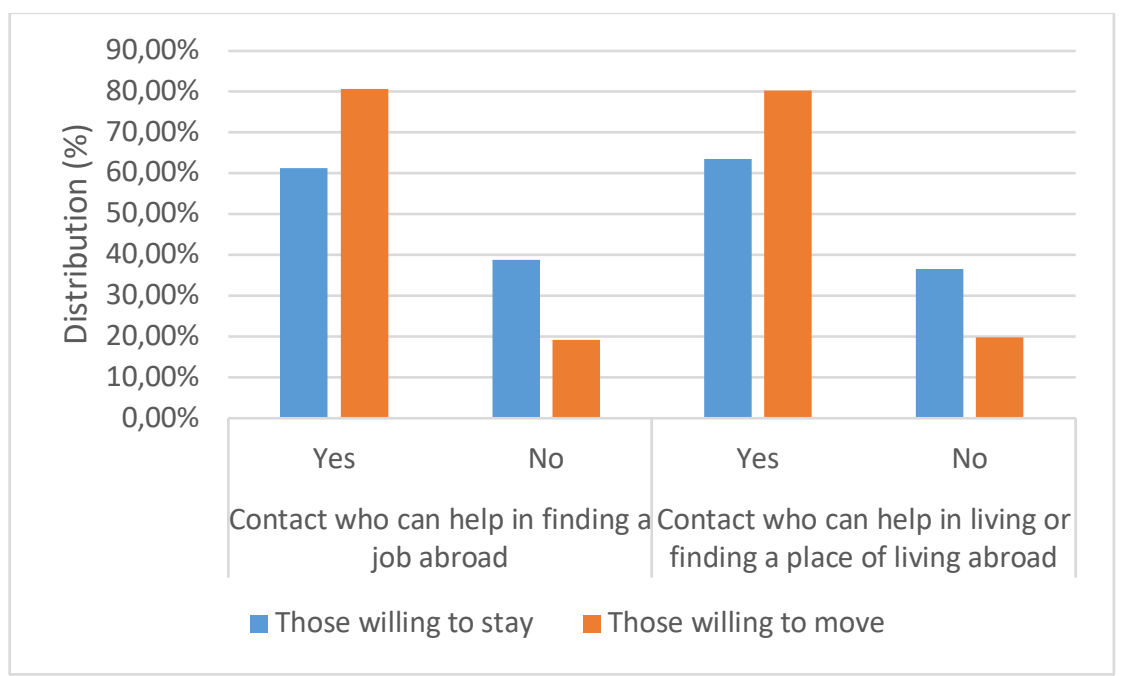

Chi-square test, $\mathrm{p} \leq 0,05$.

Figure 1. The foreign relations of those willing to stay and willing to move abroad. Source: PSQLMA 2017.

In our research, we also examined how the relationship network directly surrounding the doctoral student, i.e. embeddedness, influences the intention to migrate. In our study, doctoral students' embeddedness is measured along two dimensions which are the index of belonging to a

3 The typical PhD student who has already lived abroad is young (max. 34 years old), male and his parents have got high qualifications. 
local community and that of the family/friendship system. For the former, membership in sports clubs, arts, hobby or leisure clubs, religious affiliation and religiosity defined by Tomka (1973) are cumulative. The latter includes marital status, relationship with friends, relatives and acquaintances, i.e. frequency of personal meeting and conversation. First, we describe the variables of embeddedness.

According to the self-categorization of doctoral students, $33 \%$ of the respondents are religious in their own way, with $12 \%$ following the teachings of the Church. These values differ from the results of research conducted in the region. At least one in two respondent students considers himself/herself to be religious in their own way, with about $15 \%$ to $25 \%$ more strongly attached to the Church (Hodossi \& Márkus, 2016; Pusztai, 2013).

Measuring the question 'Are you a member of a religious community?', a low level of religious commitment can be observed too, as the proportion of respondents who claim to belong to a religious community is negligible. $19.3 \%$ of the responding doctoral students reported belonging to a religious community, but the high non-response rate $(26.7 \%)$ is also should be noted.

Patterns of leisure activities, arts, sports, or other hobby groups, professional clubs are volunteered but organized communities that are characterized by predetermined rules and principles of operation where weak links can be built in order to strengthen individual resources (Huszti, 2014; Utasi, 2013; Weber, 1987).

The surveyed doctoral students are mostly members of leisure organizations and hobby groups (22.1\%), followed by sports club membership (18.1\%) and participation in an artistic group $(10.8 \%)$. We also considered it important to examine the strengths and weaknesses of PhD students in their residence. Close family members, relatives and friends are strong bonds while neighbours and acquaintances are weak bonds (Granovetter, 1982, 1983).

Regarding marital status, $42.3 \%$ of the doctoral students studied are married, or in cohabitation, $27.6 \%$ are in a relationship, $27.6 \%$ are single, and $2.6 \%$ are divorced.

Regarding the deprivation of friends as an indicator of social isolation, the responding doctoral students are not exposed to isolation. 93.9\% reported having a friend with whom they can discuss any kind of problems, and the proportion of those who do not make any contact outside the family is negligible (6.1\%). They count on help only within the family, either emotionally or instrumentally.

The participants are in daily contact with relatives while weekly contact with friends. Of course, due to their class-specific isolation, highly educated $\mathrm{PhD}$ students establish fewer relationships with their neighbours compared to those with low educational level and low status (Huszti, 2012).

After discussing the variables of belonging to a local community and family/friendships, we combined the variables and measured how embeddedness as a combined indicator influences the intention to migrate. The results of the ANOVA test in Table1 show a significant difference $(p=0.039)$ in the embeddedness of those intending to stay and those wishing to go abroad. The average embeddedness index of those who want to go abroad is significantly lower than those who want to stay in the homeland.

Based on these, it can be stated that the results of the examined doctoral students correspond with the results of some previous researches according to which strong bonding in the immediate environment reduces the likelihood of migration (Deákné Dusa, 2017; Haug, 2008; Székely \& Pitó, 2010).

Table 1. The embeddedness of PhD students and the propensity of migration. Source: PSQLMA 2017.

\begin{tabular}{cccc} 
& Mean & $\mathbf{N}$ & SD \\
\hline Those willing to stay & 7,1395 & 43 & 1,37289 \\
\hline Those willing to move & 6,5088 & 57 & 1,58253 \\
\hline Total & 6,7800 & 100 & 1,52143 \\
\hline
\end{tabular}

ANOVA, $\mathrm{p} \leq 0,05$. 
Factors such as a higher standard of living, more attractive job opportunities and seeking for better financial conditions may be behind the migration potential.

These are primarily objective motivational factors, but the value and subjective evaluation (courage, open-mindedness, risk-taking) of the potential migrant may also be in the background (Horváth \& Kmetty, 2008).

The PhD students completing the questionnaire indicated in a 10-item block why they wanted to go abroad. Multiple answers were allowed, items were also marked by those wishing to stay.

Reasons behind the intention to migrate included gaining experience, developing a career, meeting new challenges, hope for a better quality of life, family-related reasons, lower costs of living, relocation of job, emergency situation, hope for a better livelihood and sparkling social life.

Among the examined doctoral students, the main reasons were career development (52.9\%), gaining experience $(52.4 \%)$, better livelihood (50.8\%) and achieving a better quality of life (50.3\%).

\section{Summary}

In our study, we investigated the migration potential of $\mathrm{PhD}$ students at the University of Debrecen. Also, we explored the difference between the two groups, those willing to stay in the homeland and those willing to go abroad, based on the PSQLMA 2017 database. Only PhD students of the University of Debrecen having active status in the spring semester of 2016/2017 and the autumn semester of 2017/2018 were included in the analysed database.

We examined the percentage of $\mathrm{PhD}$ students who considered leaving Hungary for a shorter or longer period after completing their academic education. About one in two respondent $\mathrm{PhD}$ students intend to settle abroad, which is motivated by the challenge, gaining experience, and reaching a better quality of life, in addition to financial reasons. The migration intentions of the examined doctoral students are independent of gender, age, marital status, source of mobility capital and educational level of parents. Groups at risk of migration include those with a migration shell and those whose strong and weak bonds at the settlement are not too strong or even missing.

Funding: This research received no external funding.

\section{References}

1. Ajzen, I. (1991). The theory of planned behavior. Organizational Behavior and Human Decision Processes, 50(2), 179-211.

2. Ajzen, I. (2005). Attitudes, Personality and Behavior (Second Edition). England: Open University Press.

3. Berényi D. (1993). Brain drain in positive view. [Az „agyelvonás” pozitív megközelítésben.] Magyar Tudomány, 9, 1111-1115.

4. Bernát A. (2006). The importance of networking in the migration - in an ethnic perspective. [A kapcsolathálózat jelentősége a migrációban-etnikai metszetben.] In: Némedi D. et al. (eds). Linking-marks. [Kötó-jelek.] Az ELTE Szociológia Doktori Iskola Évkönyve. Budapest: ELTE Társadalomtudományi Kar Doktori Iskolája, 123-146.

5. Blaskó Zs. \& Gödri I. (2014). Emigration from Hungary: Selection and choice of destination among 'new migrants'. [Kivándorlás Magyarországról: Szelekció és célország-választás az „új migránsok” körében.] Demográfia, 57(4), 271-307.

6. Blaskó Zs., Ligeti A. S. \& Sik E. (2014). Hungarians abroad. How many? Who? Where? [Magyarok külföldön. Mennyien? Kik? Hol?] In: Kolosi T. \& Tóth I. Gy. (eds.). Social repost 2014. [Társadalmi Riport 2014.] Budapest: TÁRKI, 351-372.

7. Csermely P., Málnási-Csizmadia A. \& Kovács M. (2002). How can we bring home the talented young Hungarian researchers working abroad? [Hogyan hozhatnánk haza a külföldön dolgozó, tehetséges fiatal magyar kutatókat?] Magyar Tudomány, 47(12), 1668-1675.

8. Dabasi Halász Zs. \& Kiss J. (2018). Mapping the mobility of young people. Results of the MOVE project survey in Hungary. [A fiatalok mobilitásának feltérképezése. A MOVE projekt magyarországi kérdoíves adatfelvételének eredményei.] In: Siskáné Szilasi B. \& Halász L. (eds). To prosper at home or abroad. Recent trends in emigration to Hungary. [Boldogulni itthon vagy külföldön. Legújabb trendek a magyarországi kivándorlásban.] Miskolc: Miskolci Egyetem, 142-156. 
9. Deákné Dusa Á. (2017). Internationalization at the University of Debrecen. Student mobility as a goal and a means of internationalization. [Nemzetköziesedés a Debreceni Egyetemen. A hallgatói mobilitás mint a nemzetköziesedés célja és eszköze.] PhD-értekezés. Debrecen: Debreceni Egyetem.

10. Douglas, S. M. et al. (1993). Theories of International Migration: A Review and Appraisal. Population and Development Review, 19(3), 431-466.

11. Fassmann, H. \& Musil, E. (2013). Conceptual Framework for modelling longer term migratory, labour market and human capital processes. Wien: Universität Wien.

12. Földvári M. (2014). Perspectives of religion sociology. Religion and spirituality in Hungary in the light of nationally representative studies. [Vallásszociológiai perspektívák. Vallásosság és spiritualitás Magyarországon országosan reprezentatív vizsgálatok tükrében.]Kapocs, 13(4), 55-63.

13. Gábrity-Molnár I. (2008). A vision of our education - a reading of educational sociology. [Oktatásunk látleleteoktatásszociológiai olvasmány.] Szabadka: Újvidéki Egyetem.

14. Garai O. et al. (2010). Graduate Career Track IV. Fresh Graduates 2010. [Diplomás pályakövetés IV. Frissdiplomások 2010.] Budapest: Educatio Társadalmi Szolgáltató Nonprofit Kft., Felsőoktatási Osztály.

15. Gödri I. \& Feleky G. A. (2013). Implementation of migration plans in the light of a follow-up study. The role of prior migration intention, expectations and external expectations. [Migrációs tervek megvalósulása egy követéses vizsgálat tükrében. Az előzetes migrációs szándék, a várakozások és a külső elvárások szerepe.] Demográfia, 56(4), 281-332.

16. Golovics J. (2015). The relevance of brain drain int he 21st century. [Az agyelszívási adó relevanciája a XXI. században.] In: Keresztes G. (ed.). Spring wind 2015. Conference book II. [Tavaszi Szél 2015 Konferenciakötet II.] Eger: Líceum Kiadó,383-397.

17. Granovetter, M. (1982). The power of weak bonds. [A gyenge kötések ereje.] In: Angelusz R. \& Tardos R. (eds.). The hidden network of our society. [Társadalmunk rejtet hálózata.] Budapest: Magyar Közvéleménykutató Intézet, $371-400$.

18. Granovetter, M. (1983). The Strenght of Weak Tief: A Network Theory Revisited. Sociological Theory, 1, 201233.

19. Haug, S. (2008). Migration networks and migration decision-making. Journal of Ethnic and Migration Studies, 34(4), 585-605.

20. Hautzinger Z., Hegedüs J. \& Klenner Z. (2014). The theory of migration. [A migráció elmélete.] Budapest: Nemzeti Közszolgálati Egyetem Rendészettudományi Kar.

21. Hegedűs R. (2015). Connection between Educational Mobility and Higher Education Institutions. In: Matei L. \& Berács J. (eds.) Central European Higher Education Cooperation Conference Proceedings. Budapest: Corvinus University of Budapest Digital Press, 114-123.

22. Hodossi S. \& Márkus Zs. (2016). Religiosity and health. Religiosity as social proceting factor. [Vallásosság és egészség. A vallásosság mint társadalmi védőfaktor.] In: Pusztai G., Bocsi V. \& Ceglédi T. (eds.). The added value of higher education. [A felsőoktatás hozzáadott értéke.] Partium Könyvkiadó, Personal Problems Solution. Új Mandátum Kiadó, 278-289.

23. Horváth Á. \& Kmetty Z. (2008). Do they think else about the world? The values of Hungarian graduates living abroad. [Mást gondolnak a világról? A külföldön élő magyarországi diplomások értékrendje.] In: Füstös L., Guba L. \& Szalma I. (eds.). Social registry 2008/1. [Társadalmi regiszter 2008/1.] Budapest: Társadalomtudományi Kutatóközpont. Politikatudományi Intézet. Magyar Tudományos Akadémia Kiváló Kutatóhely, 153-171.

24. Huszti É. (2012). Social Relationships. Family, relatives and friendships among the inhabitants of Nyíregyháza 2008-2010. [Társas kapcsolatok. Családi, rokoni, baráti kapcsolatok Nyíregyháza lakói körében 2008-2010.] Acta Medicinae et Sociologica, 3(3), 155-176.

25. Huszti É. (2014). Social Relationships in Nyíregyháza. [Társas kapcsolatok Nyíregyházán.] Acta Medicinae et Sociologica, 5(12-13), 143-164.

26. Huzdik K. (2014). The development of migration potential and factors influencing it in the first decade of the 10th century in Hungary. [Migrációs potenciál alakulása, és az azt befolyásoló tényezók a XXI. század elsó évtizedében Magyarországon.] PhD értekezés. Gödöllő: Szent István Egyetem Gazdálkodás és Szervezéstudományok Doktori Iskola.

27. Kisfalusi D. (2012). The socio-demographic characteristics of migrants, their cultural and social resources, their migration objectives and motivations. [A bevándorlók szociodemográfiai jellemzői, kulturális és társadalmi erőforrásokkal való ellátottsága, migrációs céljaik és motivációik.] In: Göncz B., Lengyel Gy. \& Tóth L. (eds.). Immigrants in the Light of Hungarian Society: Dignity, Justice and Civic Integration. [Bevándorlók a 
magyar társadalom tükrében: Méltóság, igazságosság és civil integráció.] Budapest: Budapesti Corvinus Egyetem, 19-59.

28. Kley, S. (2011). Explaining the stages of migration within a life-course framework. European Sociological Review, 27(4), 469-486.

29. Kley, S. \& Mulder, C. H. (2010). Considering, planning, and realizing migration in early adulthood. The influence of life-course events and perceived opportunities on leaving the city in Germany. Journal of Housing and the Built Environment, 25(1), 73-94.

30. Murphy-Lejeune, E. (2002). Student Mobility and Narrative in Europe: The New Strangers. Psychology Press.

31. Németh B. \& Lőrincz L. (2019). Researches on networking regarding the domestic migration. [Hálózati hatások a belföldi migrációban.] Szociológiai Szemle, 29(1), 117-145.

32. Pálinkó É. (2013). Damaged ny brain drain and brain loss. [Agyelszívástól és agyvesztéstól sújtva.] http://figyelo.hu/cikk_print.php?cid=agyelszivastol-es-agyvesztestol-sujtva.

33. Papp Z. A. \& Csata Zs. (2014) Hungarian PhD students abroad: international contexts and specificities of the Carpathian Basin. Minorities Research, 17, 100-134.

34. Pitó K. (2015). Migration of Hungarian healthcare workers from Transylvania to Hungary. [Erdélyi magyar egészségügyi dolgozók Magyarországra vándorlása.] PhD-értekezés. Budapest: Budapesti Corvinus Egyetem.

35. Portes, A. (2008). Migration and Social Change: Some Conceptual Reflections. Princeton: Princeton University.

36. Portes, A. \& Sensebrenner J. (1998). Embeddedness and Immigration: Comments on the Social Determinants of Economic Action. [Beágyazottság és bevándorlás: megjegyzések a gazdasági cselekvés társadalmi meghatározóiról.] In: Lengyel Gy. \& Szántó Z. (eds.). Types of capital: Sociology of social and cultural resources. [Tókefajták: A társadalmi és kulturális erőforrások szociológiája.] Budapest: AULA Kiadó, 281-317.

37. Pusztai G. (2013). Student religiosity and higher education embeddedness. [Hallgatói vallásosság és felsőoktatási beágyazottság.] Confessio, 32(1), 44-57.

38. Pusztai G. et al. (2016). Knowledge Brokers in the Heart of Europe: International Student and Faculty Mobility in Hungarian Higher Education. HERJ, 6(1), 60-75.

39. Ruff T. (2012). Youth mobility: willingness, opportunities and plans. [Ifjúsági mobilitás: hajlandóság, lehetőségek és tervek.] In: Székely L. (ed.). Hungarian Youth 2012. Studybook. [Magyar Ifjúság 2012. Tanulmánykötet.] Budapest, Kutatópont, 152-178.

40. Sik E. (ed.) (2012). The sociology of migration. [A migráció szociológiája.] Budapest: ELTE Tátk.

41. Sik E. (2018). Migration shell and migratio potential. [Migrációs burok és migrációs potenciál.] In: Siskáné Szilasi B. \& Halász L. (eds). To prosper at home or abroad. Recent trends in emigration to Hungary. [Boldogulni itthon vagy külföldön. Legújabb trendek a magyarországi kivándorlásban.] Miskolc: Miskolci Egyetem, 106-127.

42. Sik E. \& Szeitl B. (2016). Migration gap in Hungary nowadays. [Migrácós szándékok a mai Magyarországon.] In: Blaskó Zs. \& Fazekas K. (eds.). Mirror of labour market 2015. [Munkaerópiaci Tükör 2015.] Budapest: MTA Közgazdaság- és Regionális Tudományi Kutatóközpont, 54-58.

43. Sik E. \& Örkény A. (2003). The emergence of migration potential. [A migrációs potenciál kialakulásának mechanizmusa.] In: Örkény A. (ed.). To go or stay? Discount law and migration expectations. [Menni vagy maradni? Kedvezménytörvény és migrációs várakozások.] Budapest: MTA Kisebbségkutató Intézet, 188-200.

44. Simonovits B. (2003). The effect of migration shell on migration potential. [A migrációs burok hatása a migrációs potenciálra.] In: Örkény A. (ed.). To go or stay? Discount law and migration expectations. [Menni vagy maradni? Kedvezménytörvény és migrációs várakozások.] Budapest: MTA Kisebbségkutató Intézet, Nemzetközi Migrációs és Menekültügyi Kutatóközpont, 143-149.

45. Siskáné Szilasi B. \& Halász L. (2018). Selective migration with socio-demographic and economic explanations. [Szociodemográfiai és gazdasági magyarázatú szelektív migráció.] In: Siskáné Szilasi B. \& Halász L. (eds). To prosper at home or abroad. Recent trends in emigration to Hungary. [Boldogulni itthon vagy külföldön. Legújabb trendek a magyarországi kivándorlásban.] Miskolc: Miskolci Egyetem, 48-55.

46. Stark, O., Helmenstein, C. \& Prskawetz, A. (1997). A brain gain with a brain drain. Economics Letters, 55(2), 227-234.

47. Székely L. \& Pitó K. (2010). Does the train go on without them? Mobility history and willingness among young people in Hungary. [Nélkülük megy a vonat tovább? Mobilitási történet és hajlandóság a magyarországi fiatalok körében.] Új Ifjúsági Szemle, 8(2), 38-62.

48. Teperics K. (2003). Cross-border cooperation in secondary education in north-eastern Hungary. [Határmenti együttmúködések északkelet-Magyarország középfokú oktatásában.] In: Süli-Zakar I. (ed.). Borders and Borderlessness in Transforming Central Europe. [Határok és határmentiség az átalakuló közép-Európában.] Debrecen: Kossuth Egyetemi Kiadó, 112-120. 
49. Tilly, C. \& Brown, C. H. (1967). On Uprooting, Kinship, and Auspices of Migration. International Journal of Comparative Sociology, 8(2), 139-164.

50. Tomka M. (1973). The measurement of religiosity. [A vallásosság mérése.] Magyar Pszichológiai Szemle, 1-2, 122-135.

51. Utasi Á. (2002). A network of trust. Micro-social relations and solidarity. [A bizalom hálója. Mikrotársadalmi kapcsolatok és szolidaritás.] Budapest: Új Mandátum Kiadó.

52. Utasi Á. (2013). In ties. Solidarity networks and public life. [Kötelékben. Szolidaritás-hálók és közélet.] Szeged: Belvedere.

53. Virág Á. (2015). Investigation of the natural social safety net in a client circle of a Nyíregyháza foundation. [A természetes szociális védőháló vizsgálata egy nyíregyházi alapítvány klienskörében.] Acta Medicinae et Sociologica, 6, 103-124.

54. Weber, M. (1987). Economy and society. Basic lines of understanding sociology I. [Gazdaság és társadalom. A megértó szociológia alapvonalai I.] Budapest: Közgazdasági és Jogi Könyvkiadó.

(C) 2020 by the authors. Submitted for possible open access publication under the terms and conditions of the Creative Commons Attribution (CC BY) license (http://creativecommons.org/licenses/by/4.0/). 